\title{
Penggunaan Multimedia Interaktif Model Simulasi Untuk Meningkatkan kemampuan Analisis Mahasiswa di IPI Garut. (Quasi Eksperimen pada Praktikum Fisiologi Hewan Jurusan Pendidikan Biologi IPI Garut)
}

\author{
Siti Nurkamilah \\ Jurusan Pendidikan Biologi Fakultas FMIPA \\ Institut Pendidikan Indonesia \\ Email : stnk16@gmail.com
}

\begin{abstract}
This research is based on the low level of student ability analysis on IPI Garut. To over come this, done research in Animal Physiology practical lectures using interactive multimedia simulation models. This research examines the problem of increased analysis capabilities of students using interactive multimedia with students who use conventional learning methods. This research is a research quasy experiments with making purposive sampling technique using samples. The population of this research is to study all students who take Biology education course of animal Physiology lesson in 2014/2015. The sample of this research is a students of class B and class C. instrument used in this research in the form of test analysis capabilities. Analysis date was carried out quantitatively. Analysis date capability analysis done with test Mann Whitney U to pretest and N-Gain. The research results showed that improved analysis capabilities of students who used simulation models interaktif multimedia better than students who do not used interactive multimedia in the teaching of animal physiology of the digestive system in Paramecium sp at IPI in Garut. Based on the results, it is recommended to use interactive multimedia simulations models can be used in practical of Biology education courses to enchance students analysis capability, especially in organizing aspect. Then, on further research is expected to examine the use of interactive multimedia simulation models to improve the students ability in other areas, such as psychomotor or affective.
\end{abstract}

Key words: Analysis capabilities, multimedia interactive simulation models

Abstrak - Penelitian ini didasarkan pada rendahnya kemampuan analisis mahasiswa di IPI Garut. Untuk mengatasi hal tersebut, dilakukan penelitian dalam perkuliahan praktikum Fisiologi Hewan dengan menggunakan multimedia interaktif model simulasi. Penelitian ini mengkaji masalah peningkatan kemampuan analisis mahasiswa yang menggunakan multimedia interaktif dengan mahasiswa yang menggunakan metode pembelajaran konvensional. Penelitian ini merupakan penelitian quasi eksperimen 
dengan pengambilan sampelnya menggunakan teknik purposive sampling. Populasi penelitian ini adalah semua mahasiswa Program Studi Pendidikan Biologi yang mengambil mata kuliah Fisiologi Hewan tahun pelajaran 2014/2015. Sampel penelitian ini adalah mahasiswa kelas B dengan kelas C. Instrumen yang digunakan dalam penelitian ini berupa tes kemampuan analisis. Analisis data dilakukan secara kuantitatif. Analisis data Kemampuan analisis dilakukan dengan uji Mann Whitney-U untuk pretes dan $N$-Gain. Hasil penelitian menunjukan bahwa Peningkatan kemampuan analisis mahasiswa yang menggunakan multimedia interkatif model simulasi lebih baik daripada mahasiswa yang tidak menggunakan multimedia interaktif dalam praktikum fisiologi hewan mengenai sistem pencernaan pada Paramecium sp di IPI Garut. Berdasarkan hasil penelitian, diajukan saran agar Multimedia interaktif model simulasi dapat digunakan dalam praktikum di Program Studi Pendidikan Biologi untuk meningkatkan kemampuan analisis mahasiswa, khususnya dalam aspek mengorganisasikan. Kemudian, pada penelitian selanjutnya diharapkan dapat mengkaji penggunaan multimedia interaktif model simulasi untuk meningkatkan kemampuan mahasiswa dalam kawasan lainnya, baik itu dalam kawasan afektif maupun psikomotorik.

\section{Kata Kunci: Kemampuan analisis, Multimedia Interaktif Model Simulasi}

\section{PENDAHULUAN}

Pembelajaran pada hakikatnya merupakan cara yang dilakukan agar peserta didik dapat menemukan jati diri dan hakikat kehidupan yang sebenarnya. Seperti diutarakan oleh Gordon, et al (2004:2) "Goal behavior can be categorized into two typesmaster and performance. A mastery goal is oriented learning such as possible for the purpose of selfimprovement, irrespective of the performance of other. A a porfermance foal focuses on sosial comparison and competition, eith the main purpose of out performing others, with the main purpose of outperforming others on the task". Dengan adanya proses pembelajaran yang baik, maka diharapkan peserta didik dapat mencapai tujuan pembelajaran yang baik pula baik itu tujuan yang bersifat individu atau berguna bagi dirinya maupun bagi lingkungan sosialnya. Peserta didik diharapkan tidak hanya dapat menghapal berbagai materi pelajaran saja namun peserta didik dapat mengaplikasikannya dalam kehidupan sehari-hari sehingga pada akhirnya mereka dapat membedakan mana yang baik dan mana yang buruk dalam kehidupan. Tujuan pembelajaran tersebut akan mudah tercapai jika peserta didik memiliki beberapa kemampuan khusus, diantaranya kemampuan dalam mengolah berbagai informasi dan menunjukan hubungan antar informasi terseb kemampuan individu untuk menentukan bagianbagian dari suatu masalah dan menunjukkan hubungan antar bagian tersebut, melihat penyebab-penyebab dari suatu peristiwa atau memberi argumen-argumen yang menyokong suatu pernyataan atau bisa disebut kemampuan analisis. Kemampuan analysis merupakan salah satu kemampuan yang utama yang harus dimiliki oleh peserta didik khususnya mahasiswa, karena dalam materi perkuliahaan khususnya praktikum, peserta didik dituntut untuk menjelaskan hasil praktikum dan hubungan sebab akibat dari teori yang ada dengan hasil yang diperoleh. Namun fenomena yang terjadi pada saat 
ini adalah masih banyak peserta didik yang memiliki kemampuan analisis yang kurang dalam proses pembelajaran. Hal itu sebenarnya dapat diatasi dengan berbagai cara, salah satunya adalah dengan memanfaatkan media pembelajaran yang ada di sekolah. Penggunaan media pembelajaran yang menarik dengan menggunakan multimedia, maka akan tercipta kemampuan analisis yang baik pada peserta didik. Berdasarkan hasil pengamatan sementara proses pembelajaran dalam praktikum fisiologi hewan di IPI Garut Program Studi Pendidikan Biologi belum berjalan dengan baik, hal ini dapat dibuktikan dengan kemampuan analisis peserta didik yang kurang selama mengikuti pembelajaran. Dalam proses praktikum, kemampuan analisis peserta didik masih kurang karena terdapat beberapa kesulitan dalam tahapan praktikum yang dilakukan, kekurangan dalam kemampuan analisis ini dapat dilihat dari hasil dari praktikum dan rata-rata nilai hasil pembelajaran yang didapatkan dari praktikum belum sesuai dengan tujuan pembelajaran dan ketuntasan yang diharapkan.

Berdasarkan permasalahan pembelajaran mengenai kurangnya kemampuan analisis peserta didik dengan menggunakan multimedia interaktif sebagai solusinya ,maka peneliti melakukan penelitian yang berjudul "Penggunaan Multimedia Interaktif Model Simulasi Untuk Meningkatan Kemampuan Analisis Mahasiswa Di IPI Garut Tahun Akademik 2014/1015".Penulis merumuskan masalah sebagai berikut, “ apakah penggunaan multimedia interaktif model simulasi dapat meningkatkan minat belajar dan kemampuan analisis mahasiswa di IPI Garut?". Secara umum penelitian ini bertujuan untuk menghasilkan multimrdia interaktif model simulasi untuk meningkatkan kemampuan analisis mahasiswa. Hasil penelitian ini diharapkan dapat bermanfaat bagi dunia pendidikan khususnya dalam matakuliah praktikum Fisiologi Hewan.

\section{LANDASAN TEORI}

a. Pendidikan Dan Pembelajaran Pendidikan merupakan suatu hak yang mutlak dimiliki oleh setiap warga Negara. Pendidikan memiliki ruang lingkup yang sangat luas, mencangkup semua pengalaman dan pemikiran manusia menganai pendidikan. Perbuatan mendidik bukan suatu perbuatan serampangan, melainkan suatu perbuatan yang betul-betul didasari dan disadari dalam rangka membimbing manusia pada suatu tujuan yang akan dicapai (Sadulloh, 2003:2). Tujuan dari pendidikan tidak hanya mengacu pada nilai yang ingin dicapai, tapi tujuan dari pendidikan yang sebenarnya adalah terjadinya perubahan perilaku, perubahan dari yang awalnya tidak tahu menjadi tahu, dari yang tidak bisa menjadi bisa dari yang tidak dapat membedakan mana yang baik dan mana yang salah menjadi bisa membedakan antara yang baik dengan yang salah.). Faktor-faktor yang berpengaruh terhadap proses pembelajaran, antara lain faktor siswa, guru, sarana dan prasarana, serta lingkungan. Siswa merupakan organisme untuk yang berkembang sesuai dengan tahap perkembangannya (Sanjaya: 2011: 17).

\section{b. Teknologi Pendidikan}

Teknologi pendidikan memang erat kaitannya dengan penggunaan media di sekolah karena teknologi memiliki fungsi mempermudah manusia dalam melakukan kegiatan sehari-hari. teknologi peembelajaran menurut AECT, 1977 adalah teknologi 
pembelajaran adalah proses kompleks yang terintegrasi meliputi: orang, prosedur, gagasan, sarana dan organisasi untuk menganalisis masalah dan merancang, melaksanakan, menilai, dan mengelola pemecahan masalah dalam segala aspek belajar pada manusia (Warsita, 2008:). Teknologi pembelajaran dirumuskan dengan berlandaskan pada lima bidang garapan bagi teknologi pembelajaran atau yang biasa disebut dengan kawasan teknologi pembelajaran (Darmawan, 2012:4). Adapun kawasan-kawasa tersebut antara lain adalah kawasan desain, kawasan pemanfaatan, kawasan pengelolaan, dan kawasan penilaian.

c. Multimedia Interaktif

Media pembelajaran adalah segala sesuatu yang dapat digunakan untuk menyalurkan pesan dari pengirim ke penerima sehingga dapat merangsang pikiran, perasaan, perhatian, dan minat serta perhatian siswa sedemikian rupa sehingga proses pembelajaran terjadi (Sadiman, 2007: 7). Menurut Robin, Linda (dalam Darmawan, 2012: 47) “ multimedia adalah alat yang dapat menciptakan presentasi yang dinamis dan interaktif yang mengkombinasikan teks, grafik, animasi, audio, dan video". Sedangkan model multimedia interaktif yang terakhir dan sekaligus menjadi model multimedia interaktif yang digunakan oleh peneliti dalam penelitian ini adalah multimedia interaktif model simulasi. Pada dasarnya penerapan multimedia interaktif model ini adalah memberikan tiruan-tiruan nyata atau percontohanpercontohan yang lebih real mengenai proses pembelajaran yang dijalani. Model simulasi tebagi ke dalam empat kategori, yaitu fiksi, situasi, prosedur, dan proses yang masing-masing kategori tersebut digunakan sesuai dengan kepentingan tertentu (Darmawan, 2012: 65).

\section{d. Kemampuan Analisis}

Kemampuan analisis merupakan kemampuan kognitif yang sering dijadikan tujuan pembelajaran oleh pendidik. Namun, seorang peserta didik yang memahami suatu materi pelajaran belum tentu dapat menganalisis pelajaran. Kategori proses menganalisis meliputi proses-proses kognitif membedakan, mengorganisasi, mengatribusikan ( Logman, 2010: 120). Dengan adanya daya analisis yang baik, maka peserta didik akan terbiasa dalam menemukan dan memahami konsep pembelajaran, sehingga pada akhirya akan memudahkan peserta didik dalam mengaplikasikan materi yang dipelajari dari proses pembelajaran.

e. Materi Perkuliahan

Materi perkuliahan yang dijadikan bahan penelitian adalah materi perkuliahan fisiologi hewan. Fisiologi adalah fungsi kerja yang meliputi fungsi mekanik, fisik, dan biokimia dari mahluk hidup. Berdasarkan bidangnya, fisiologi dibedakan menjadi dua bagain, yaitu fisiologi hewan dan fisiologi tumbuhan. Dalam fisiologi hewan banyak dibahas pula berbagai aktivitas fisiologis dari mahluk hidup khususnya mahluk hidup yang tergolong dalam hewan. . Semua kehidupan ditandai dengan tingkat organisasi yang berhirarki (Neil,2004:4). Pada protozoa, proses pencernaannya terjadi dalam vakuola. Mula-mula, lisosom menyekresikan enzim pencernaan ke dalam vakuola makanan. Enzim tersebut menyebabkan suasana vakuola berubah menjadi asam sehingga bahan makanan tercerna. Selanjutnya, terjadi pemisahan berbagai garam kalsium. Hal ini akan menciptakan suasana lingkungan dengan $\mathrm{pH}$ yang tepat bagi berbagai enzim untuk berfungsi secara optimal. Dalam keadaan seperti itu, bahan makanan akan disederhanakan sehingga dapat diserap oleh sitoplasma. 
Berakhirnya proses pencernaan ditandai dengan adanya perubahan keadaan lingkungan dalam vakuola menjadi netral. Bahan makanan yang tidak tercerna dikeluarkan melalui proses eksositosis.

\section{METODOLOGI PENELITIAN}

Metode peenelititan yang digunakan dalam penelitian ini adalah metode penelitian eksperimen dengan pendekatan kuantitatif. Sedangkan desain eksperimennya menggunakan Quasi eksperimental. Kemudian untuk pengambilan sampel dilakukan secara purposive sampling.

Penelitian ini dilakukan di Program studi Pendidikan Biologi IPI Garut , Jalan Pahlawan No. 32 Tarogong Kidul Garut.

Populasi pada penelitian ini adalah mahasiswa Pendidikan Biologi IPI Garut yang mengambil mata kuliah praktikum Fisiologi Hewan, sebanyak 90 orang. Sedangkan sampel penelitian adalah 60 orang mahasiswa yang mengontrak mata kuliah fisiologi hewan tahun ajaran 2014/2015 yang memiliki kemampuan sedang dan rendah dalam mata kuliah Praktikum Fisiologi Hewan. Kemudian, Instrumen penelitian yang digunakan adalah tes pilihan ganda sebanyak 20 soal dengan lima pilihan jawaban.

\section{HASIL PENELITIAN DAN PEMBAHASAN}

Gambaran umum Kemampuan analisis Mahasiswa Jurusan Pendidikan Biologi di IPI Garut Tahun Akademik 2014/2015 sebelum dilakukan penelitian dapat dilihat pada tabel berikut :

Tabel 1. Kemampuan analisis Mahasiswa Jurusan Pendidikan Biologi di IPI Garut Tahun Akademik 2014/2015

\begin{tabular}{|l|l|l|l|}
\hline Skor & Jumlah & Persentase & Kualifikasi \\
\hline$\geq 60$ & 3 & $5 \%$ & Tinggi \\
\hline $\begin{array}{l}59- \\
50\end{array}$ & 15 & $25 \%$ & Sedang \\
\hline$<50$ & 41 & $68 \%$ & Rendah \\
\hline
\end{tabular}

Berdasarkan tabel 1 yang telah disajikan, menunjukan bahwa kemampuan analsisis mahasiswa pada mata kuliah praktikum Fisiologi Hewan secara umum tergolong rendah, sisanya tergolong tinggi dan sedang. Berdasarkan tabel di atas, maka sebanyak 56 mahasiswa yang tergolong ke dalam kualifikasi rendah dan sedang dibagi ke dalam 2 kelas, yakni kelas eksperimen dan kelas kontrol. Kelas eksperimen melakukan pembelajaran dengan menggunkan multimedia interkatif model simulasi, sedangkan kelas kontrol dengan menggunakan pembelajaran konvensional.

Kemudian untuk mengetahui ada tidaknya perbedaan kemampuan analisis mahasiswa sebelum dan setelah memberikan perlakuan terhadap kelas eksperimen dan kelas kontrol, maka dilakukan uji statistika sebagai berikut:

Tabel 2. Gambaran Umum Kemampuan analisis Mahasiswa Jurusan Pendidikan Biologi di IPI Garut Tahun Akademik 2014/2015

\begin{tabular}{|l|l|l|l|l|l|l|}
\hline \multirow{2}{*}{} & \multicolumn{3}{|c|}{ Kelas Kontrol } & \multicolumn{3}{c|}{$\begin{array}{c}\text { Kelas } \\
\text { Eksperimen }\end{array}$} \\
\cline { 2 - 7 } & N & $\begin{array}{l}\text { Rata } \\
\text {-rata }\end{array}$ & S & N & $\begin{array}{l}\text { Rata } \\
\text {-rata }\end{array}$ & S \\
\hline Prete & 3 & 47,0 & 7,3 & 3 & 45,0 & 8,4 \\
s & 0 & 3 & 8 & 0 & 7 & 4 \\
\hline Poste & 3 & 58,4 & 8,3 & 3 & 67,0 & 7,7 \\
s & 0 & 0 & 5 & 0 & 0 & 2 \\
\hline$N$ - & 3 & 0,21 & 0,1 & 3 & 0,39 & 0,1 \\
Gain & 0 & & 7 & 0 & & 5 \\
\hline \multicolumn{3}{|c|}{ Skor Maksimum Ideal 100 } \\
\hline
\end{tabular}


Berdasarkan table 2 terlihat bahwa ratarata nilai kemampuan analisis mahasiswa masih rendah dan di bawah $\mathrm{kkm}$ baik itu kelas kontrol maupun kelas eksperimen yaitu 47,03 untuk kelas kontrol dan 45,07 untuk kelas eksperimen, namun setelah dilakukan perlakuan terlihat bahwa ada kenaikan yang signifikan antara kemampuan analisis mahasiswa sebelum mendapat perlakuan dengan setelah mendapat perlakuan. Mahasiswa pada kelas eksperimen memperoleh rataan yang lebih besar daripada kelas kontrol. Besarnya kenaikan rataan untuk kelas kontrol dari pretes ke postes adalah sebesar 11,37, sedangkan kenaikan rataan kelas eksperimen dari pretest ke postes sebesar 21,93. Secara sepintas, nilai kenaikan ini menunjukan bahwa kenaikan rataan kemampuan analisis mahasiswa pada kelas eksperimen lebih besar daripada kelas kontrol. Kemudian untuk melihat kenaikan nilai dapat terlihat dari rata-rata nilai postes kelas kontrol rata-rata mendapatkan nilai 58,40 yang masih dibawah kkm yang diterapkan sebasar 60, sedangkan ratarata nilai kelas eksperimen adalah 67 . Nilai ini lebih besar daripada kkm yang ada.

Untuk menguji perbedaan penggunaan multimedia interaktif model simulasi terhadap peningkatan kemampuan analisis setelah pembelajaran antara kelas eksperimen dan kelas kontrol digunakan uji Mann Whitney dengan bantuan program SPSS versi 20.0 yang hasil analisis datanya dapat dilihat pada tabel berikut

Tabel 3. N-Gain Ternormalisasi Kemampuan Analisis

\begin{tabular}{|l|c|c|}
\hline \multicolumn{1}{|c|}{ Statistik } & Nilai & Keterangan \\
\hline $\begin{array}{l}\text { Mann } \\
\text { Whitney } U\end{array}$ & 181,500 & Ho Ditolak \\
\hline
\end{tabular}

\begin{tabular}{|l|l|l|}
\hline$Z$ & $-3,981$ & \\
\cline { 1 - 1 } & $\begin{array}{l}\text { Asymp.Sig }( \\
\text { 2-tailed) }\end{array}$ & 0,000 \\
\end{tabular}

Berdasarkan tabel 4.36, dapat dilihat bahwa nilai sig sebesar 0,000 hal ini menandakan bahwa nilai sig lebih kecil daripada $\alpha$ 0,05 maka Ho Ditolak dan Ha diterima. Artinya, terdapat perbedaan peningkatan kemampuan analisis mahasiswa yang menggunakan multimedia interaktif dengan mahasiswa yang menggunakan metode belajar konvensional. Atau dengan kata lain kemampuan analisis mahasiswa yang menggunakan multimedian interaktif lebih baik daripada minat belajar mahasiswa yang menggunakan pembelajaran konvensional.

Adapun untuk nilai rata-rata pretes dan postes mahasiswa mengalami kenaikan yang sangat signifikan. Ratarata nilai kelas kontrol mengalami kenaikan sebesar 11,37 dengan rata-rata nilai postes sebesar 58,40 yang masih dibawah KKM mata kuliah Fisiologi hewan sebesar 60. Sedangkan kelas eksperimen mengalami kenaikan ratarata sebesar 21,93 dengan rata-rata nilai postes sebesar 67,00 yang berada di atas KKM. Kemudian untuk rata-rata kenaikan kemampuan analisis mahasiswa dengan nilai N-Gian adalah 0,21 untuk kelas kontrol dan 0,39 untuk kelas eksperimen, kedua kelas ini mengalami rata-rata kenikan yang sedang, namun kelas eksperimen mengalami kenaikan yang lebih tinggi daripada kelas kontrol.

Dari hasil pengujian hipotesis $N$ Gain minat belajar diperoleh nilai sig= 0,000 hal ini menandakan bahwa nilai sig lebih kecil daripada $\alpha=0,05$ maka Ho Ditolak dan Ha diterima. Artinya, terdapat perbedaan peningkatan kemampuan analisis mahasiswa yang menggunakan multimedia interaktif model simulasi dengan mahasiswa yang 
menggunakan metode belajar konvensional. Peningkatan kemampuan analisis yang terjadi dalam penelitian ini tidak terlepas dari berbagai faktor yang memperngaruhi. Menurut Kemal (2014: 1) terdapat beberapa faktor yang mempengaruhi perkembangan kognitif peserta didik, salah satunya kemampuan analisis adalah faktor keturunan, faktor lingkungan, kematangan, pembentukan, minat bakat, kebebasan". Oleh karena itu, dengan adanya media yang ada berupa multimedia interaktif, kebebasan dalam mengesplor kemampuan diri dengan memanfaatkan pengetahuan yang ada sebelumnya dengan pengetahuan yang baru disertai berbagai tampilan media pembelajaran yang menarik akan membantu peserta didik dalam meningkatkan kemampuan analisisnya.

Dengan adanya pengalam belajar yang lebih konkret ini menjadikan mahasiswa lebih mudah membedakan, mengatribusikan dan mengorganisasikan berbagai materi perkuliahan yang diberikan. Dapat dilihat, dari kenaikan yang terjadi, yang paling tinggi kenaikannya yaitu terjadi pada aspek mengatribusikan, karena, dalam proses praktikum dengan menggunakan multimedia interaktif, mahasiswa dibiasakan untuk bebas mengeksplor kemampuan dirinya dalam memahami dan mengkaji serta berpendapat mengenai berbagai hal yang mereka temukan dalam praktikum, mereka terbiasa untuk menghubungkan berbagai materi perkuliahan yang didapatkan dalam praktikum dengan fakta di lapangan yang terjadi dalam kehidupan sehari-hari mereka.

V. Kesimpulan

Dalam praktikum fisiologi hewan, peningkatan kemampuan analisis mahasiswa yang menggunakan multimedia interaktif model simulasi, lebih baik daripada mahasiswa yang menggunakan pembelajaran konvensional Secara umum kemampuan analisis mahasiswa Jurusan Pendidikan Biologi berada pada kualifikasi rendah, terutama ada aspek mengorganisasikan yang meliputi kemampuan dalam membedakan, mendiagnosis, mengaitkan dan memilih. Namun, setelah pembelajaran dengan menggunakan multimedia interaktif model simulasi, maka terjadi peningkatan kemampuan analisis aspek mengorganisasi, selain itu, terjadi peningkatan pada aspek membedakan dan mengatribusikan.

\section{DAFTAR PUSTAKA}

[1] Abrori, saiful.(2014). Pengaruh penggunaan multimedia dan media gambar terhadap hasil belajar siswa SD. Terdapat Dalam [Http://Eprints.Uns.Ac.Id/14140/1/41 8-1078-1-PB.Pdf]

[2] Agnew, Anne, at all.,(1996). Multimedia in The Classroom. USA: MediaLink Associates, Inc.

[3] Arifin, D.(2012). Pengaruh penerapan CD multimedia Interaktif terhadap ketercapaian tujuan pembelajaran aspek mengingat dan memahami dalam pembelajaran Biologi pada materi sistem saraf. IPI Garut

[4] Arifin, Zaenal.(2013). Evaluasi Pembelajaran. Bandung: PT. Remaja Rosda Karya

[5] Arikunto, Suharsimi.(2011). DasarDasar Evaluasi Pendidikan. Jakarta: Bumi Angkaara

[6] Arsyad, A. (2007). Media Pembelajaran. Jakarta: PT. Raja Grafindo Persada

[7] Beetlestone, Florence.(1998). Creative Learning. Philadelphia: Open university Press

[8] Campbbell. (2004). Biologi (Jilid III). Jakarta: Erlangga 
[9] (2011). Biology (Nitht Edition). USA : Person Benjamin. Inc

[10] Darmawan, Deni. (2012). Inovasi Pendidikan. Bandung: PT. Remaja Rosda Karya

[11]

Teknologi Pembelajaran. Bandung: PT. Remaja Rosda Karya

[12] Daryanto. (2013). Inovasi Pembelajaran Efektif. Bandung: CV Yrama Widya.

[13] Desmita. (2012). Psikologi Perkembangan Peserta Didik. Bandung: PT. Remaja Rosda Karya

[14] Diyani, ahmad. (2013). Pengertian teknologi pembelajaran. Terdapat dalam [http://pengertianteknologi pembelajaran.html? $\mathrm{m}=1$ ]

[15] Djamarah, Syaiful. (2008). Psikologi Belajar. Jakarta: Rineka Cipta.

[16] Gordon,S dkk. Do Teachers Own Learning Behaviors influence their Classroom Goal Orientation and Control Ideology. USA : University of Southern California

[17] Hamalik, Oemar. (2006). Proses Belajar Mengajar. Bandung: Bumi Aksara.

[18] Hasibuan, Zainal.(2007). Metodologi Penelitian dalam Bidang Komputer dan Teknologi Komunikasi. Terdapat dalam [http://id.scribd.com/doc/32083714/

Buku-Referensi-Metodologi-

Penelitian-METODOLOGI-

PENELITIAN-PADA-BIDANG-

ILMU-KOMPUTER-DAN-

TEKNOLOGI-INFORMASI]

[19] Hefzallah, I.M. (2004). The New Educational Technologies and Learnig. USA : Charles C Thomas. Publisher, LTD.

[20] Hidayat, Soleh. (2013). Pengembangan Kurikulum Baru. Bandung: PT. Remaja Rosda Karya
[21] Hughes, A.G\& Hughes E.H. (2003). Learning\&Teaching. Bandung: Nuansa

[22]

http://acenale.wordpress.com/2011/1 2/21/minat-belajar/

[23]http://sumberrbelajar.files.wordpres s.com/2013/09/kawasan-teknologipendidikan.pdf

[24]http://sumberrbelajar.files.wordpres s.com/2013/09/kawasan-teknologipendidikan.pdf

[25]http://eprints.uny.ac.id/9813/2/BAB 2\%20-\%2008111241026.pdf

[26] Husaman. (2013). Fisiologi Sistem Pencernaan pada Hewan. Malang: UNM Terdapat pada [http://www.academia.edu/5612874/ SISTEM_PENCERNAAN]

[27] Isnaeni, wiwi. (2006). Fisisologi Hewan. Yogyakarta: Kanisius

[28] Kemal. (2014). Faktor yang Mempengaruhi Perkembangan Kognitif. Terdapat pada [http://permasalahananakkita.blogspo t.com/2011/02/faktor-yangmempengaruhi-perkembangan.html]

[29] Kusumawati, Dinar. (2014). Metabolisme. Terdapat pada [http://id.scribd.com/doc/6108825/M etabolisme]

[30] Logman, A. (2010). Kerangka Landasan Untuk Pembelajaran, Pengajaran dan Asesmen Revisi Taksonomi Pendidikan Bloom. Yogyakarta: Pustaka Pelajar

[31] Majid, Abdul. (2007). Perencanaan Pembelajaran. Bandung: PT. Remaja Rosda Karya [32] Mishra, S \& Sharma R. (2005). Interactive Multimedia In Education and Training.USA: Idea Group Inc

[33] Nuraeni, Eka. (2014). Kata Operasional Taksonomi Bloom Versi Terbaru untuk Jurusan Biologi. Terdapat dalam [http://www.ebookspdf.org/view/aHR0cDovL2FtY WVrYS5maWxlcy53b3JkcHJlc3Mu 
Y29tLzIwMTIvMTEva2F0YS1vcG VyYXNpb25hbC10YWtzb25vbWkt Ymxvb20tdmVyc2ktYmFydTMucG Rm/S2F0YSBPcGVyYXNpb25hbC BUYWtzb25vbWkgQmxvb20gVmV yc2kgQmFydQ==]

[34] Purwanty, Leni. (2010). Pengaruh penggunaan multimedia dalam mata pelajaran akuntansi terhadap minat, motivasi dan prestasi belajar akuntansi siswa kelas X SMK Negeri 1 Turen. Terdapat dalam [http://library.um.ac.id/freecontents/index.php/pub/detail/pengar uh-penggunaan-multimedia-dalammata-pelajaran-akuntansi-terhadapminat-motivasi-dan-prestasi-belajarakuntansi-siswa-kelas-X-smk-negeri1-turen-leny-purwanti-43042.html]

[35] Riduwan. (2008). Skala Pengukuran Variabel-Variabel Penelitian. Bandung: ALFABETHA [36] Ridwan, Wawan. (2011). Pengaruh Penggunaan Program Microsoft Excel dalam Pembelajaran Akuntansi Terhadap Peningkatan Prestasi Belajar Siswa. Garut: IPI Garut

[37] Sadiman, Arief, dkk. (2007). Media Pendidikan. Jakarta: PT. Raja Grafindo Persada.

[38] Sadulloh, Uyoh. (2003). Filsafat Pendidikan. Bandung: Alfabeta

[39] Sanjaya, Wina. (2009). Strategi Pembelajaran Berorientasi Standar Proses Pendidikan. Jakarta: Kencana Prenada Media Group [40] (2010).

Kurikulum dan Pembelajaran. Jakarta: Kencana Prenada Media Group

[41] (2011).

Perencanaan dan Desain Sistem Pembelajaran. Jakarta: Kencana Prenada Media Group

[42] Sastra, Irwan. (2014). Penerapan CD multimedia Interaktif pada pembelajaran Biologi untuk meningkatkan minat belajar siswa dan penguasaan konsep sistem pencernaan manusia. IPI Garut

[43] Seels, Barbara B. dan Richey, Rita C. (1994).Teknologi Pembelajaran Definisi dan Kawasannya.Seri Pustaka Teknologi Pendidikan No. 12. Jakarta. Unit Percetakan UNJ.

[44] Slameto. (2010). Belajar dan Faktor-Faktor yang Mempengaruhinya. Jakarta : PT. Rineka Cipta.

[45] Sudjana, Nana dan Rivai, Ahmad. (2011). Media Pengajaran. Bandung: Sinar Baru Algensindo

[46] Sugiyono. (2013). Metode Penelitian Pendidikan. Bandung: Alfabeta

[47] Sundayana, Rostina. (2014). Statistika Penelitian Pendidikan. Bandung: ALFABETA

[48] Supriadie, Didi dan Darmawan, Deni. (2012). Komunikasi Pembelajaran. Bandung: PT. Remaja Rosda Karya

[49] Surya, Mohamad. 2004. Psikologi Pembelajaran dan Pengajaran. Bandung: Pustaka Bani Quraisy [50]

Psikologi guru kosep dan aplikasi.Bandung: Alfabeta.

Syaiful Bahri Djamarah. (2008). Psikologi Belajar. Jakarta : PT. Rineka Cipta

[51] Syiamita. (2013). Ranah Kognitif dalam pembelajaran. Terlihat dalam [https://www.academia.edu/5660348/ Ranah_Kognitif_Dalam_Pembelajara n_Domain_Kognitif_Bloom_Instruct ional_Taxonomies_Bloom_Ausubel_ Anderson_Merril_und_Reigeluth]

[52] Utari, Retno. (2014). Taksonomi Bloom. Terdapat dalam [http://www.bppk.depkeu.go.id/webp kn/attachments/766_1-

Taksonomi\%20Bloom\%20\%20Retno-ok-mima.pdf] 
[53] Wahyudin. (2013). Statistika Terapan. Bandng: Mandiri

[54] Wantono. (2008). Hubungan Pemanfaatan Sarana Dan Prasarana Dalam Belajar An Motivasi Dengan Prestasi Belajar Mata Pelajaran Penjasorkes Kelas 8 Siswa SMP Negeri Kecamatan Kota Kabupaten Kudus. Terdapat pada [http://eprints.uns.ac.id/5332/1/7369 0907200904231.pdf]

[55] Warsita, B. (2008). Teknologi Pembelajaran Landasan dan Aplikasinya. Jakarta

[56] Waryanto, Hadi. (2009). Multimedia Interaktif dalam Pembelajaran. Yogyakarta: FMIPA UNY

[57] Wikipedia. (2014). Metabolisme. Terdapat pada [http://id.wikipedia.org/wiki/Metabol isme]

[458] Zainal. (2014). Pengertian dan Tujuan Pembelajaran. Terdapat pada [http://www.zainalhakim.web.id/pen gertian-dan-tujuanpembelajaran.htm] 